\title{
Deontology and Epistemic Justification: Ethics and Epistemology
}

\author{
Marta Reolon V* \\ Federal University of Rio Grande do Sul, Brazil
}

*Corresponding author: Vera Marta Reolon, Federal University of Rio Grande do Sul, Carlos Bianchini, 1149/04, Caxias do Sul, RS, Brazil, Tel: 555435384041; Email: verareolon@terra. com.br

\section{Research article}

Volume 4 Issue 2

Received Date: May 12, 2021

Published Date: June 23, 2021

DOI: $10.23880 /$ phij-16000185

\section{Abstract}

The deontological notion of epistemic justification arises from a parallel drawn between ethics and epistemology through the use of a deontological vocabulary for the assessment of an epistemic status of our beliefs. John Locke emerges as one of his most illustrious representatives. Relationship between justification and normativity. 'Epistemic duties' to explain the concept of 'epistemic justification'. Epistemic concepts are not reducible to ethical concepts. After this debate, the connection established between Ethics and Epistemology has been merely analog.

Keywords: Epistemology; Deontological; Ethics

The deontological notion of epistemic justification arises from a parallel drawn between ethics and epistemology through the use of a deontological vocabulary for the assessment of an epistemic status of our beliefs. John Locke emerges as one of his most illustrious representatives. Relationship between justification and normativity.

Deontology comes from deontos $=$ duty, logos = treated, hence deontology would be treated from duty. Study of the ethics that guides each profession. In epistemology, two theories of justification: deontological and non-deontological.

\section{Epistemic justification}

Theories of justification, two groups: deontological, which use deontic terms, similar to those used in ethics, to show the normative character of epistemic concepts; and non-deontological ones. In a line of thought, 'epistemic duties' to explain the concept of 'epistemic justification'. Epistemic concepts are not reducible to ethical concepts. After this debate, the connection established between Ethics and Epistemology has been merely analog.

\section{Epistemic Normativity}

Having knowledge is a matter of whether the world cooperates to the point of giving back justified belief with truth. If Smith can be justified in believing a false preposition, and there was nothing wrong with the way Smith acquired his belief $\Psi$, it seems plausible to assume that the sense of epistemic justification that Gettier was thinking of when presenting his counterexamples was that of to be epistemically irreproachable when believing.

Epistemic justification has an indispensable deontological component. The usual explanation of the concept of epistemic justification is associated with some deontological element.

Alvin Goldman stated that: "[d] epistemic ethologists commonly maintain that to be justified in believing a preposition $\mathrm{p}$ consists of being (intellectually) bound or authorized to believe that $p$; and to be unjustified in believing that $\mathrm{p}$ consists in not being allowed, or being prohibited, in believing that $\mathrm{p}$ "(2001, p.116) [1]. 


\section{Philosophy International Journal}

The notion of epistemic justification invoked by Gettier is in line with the deontological notion.

\section{The Origin of Duty-Based Epistemic Justification}

Chisholm and Ayer use normative terms imported from Ethics to explain the concept of epistemic justification. John Yolton comments that "distinguishing good from bad bases for belief constitutes what was called Locke's 'ethics of belief'" (1996, p.67) [2]. This view uses the notion of epistemic duties to explain the concept of "epistemic justification". The label given, very recently, to this view is that of Epistemic Deontology. For Locke, the notion of duty plays a central role in the epistemic enterprise. He is guaranteeing the normativity of his speech on the basis of belief.

Violating a duty means neglecting an important epistemic quality. Not violating an epistemic duty means not being subject to epistemic guilt or disapproval.

Believing that $\mathrm{p}$, when $\mathrm{p}$ does not seem likely $=>$ epistemically culpable.

Alvin Plantinga argues in the following terms:

To act in accordance with these duties or obligations is to be within what is right; it is to do only what is allowed; it is not subject to any guilt or disapproval; it is not to have neglected any duty; it is to be deontologically approvable; it is, in a word, to be justified. [...] epistemic justification is deontological justification; deontological justification with respect to the norm of belief (1993a, p.13-14) [3].

It is not enough to accidentally reach the truth. Acquiring true belief is not enough to make someone epistemically blameless. One may be justified in believing, even if most of his beliefs are false.

Epistemic justification, in this perspective, does not depend on any external factor or doxastic agent. Everything the subject needs to be justified belongs to his mental life.

What achieves merit to the doxastic agent and, therefore, makes it irreproachable is not to truly believe, but to believe or to stop believing according to the command of his reason. A subject's epistemic destiny should always be in his hands. It would be within the power of the subject to always do his best and be away from censorship.

Locke is clearly thinking of subjective duty or obligation, since he is thinking of innocence and guilt, responsibility and blamelessness. Being justified depends on what is accessible to the agent. But in addition to the subjective, he is also talking about an objective duty. For Locke, one must believe what is epistemically probable in relation to his total evidence. One should only believe in prepositions for which he has good reason.

Locke's objective duty would be to regulate his beliefs. Someone who does not do so, he says: "go against your own light and misuse those faculties that have been given you".

As intellectual beings, we have, what we might call, an epistemic end, the truth. The pursuit of this end imposes certain duties on us: objective and subjective epistemic duties.

\section{The use of Normative Terms}

In Epistemology, people make comparable judgments between opinions and other cognitive acts, sometimes using the same normative language. Roderick Firth and Roderick Chisholm claimed that there are deontological components at the base of epistemological concepts. Requirement, prohibition and permission can be thought of as the basic deontological terms, obligation and duty as types of requirement, and responsibility, guilt and other similar terms as derivatives. Epistemic concepts are not reducible to ethical concepts. The use of the deontological vocabulary, to make epistemic judgments, is only analogous. The connection between epistemic justification and ethical justification is also analogous.

The concept of 'justification' can be analyzed using deontological terms in a sense specifically relevant to the pursuit of knowledge.

If justification is due to fulfilling duties, then it has a normative character. To have a duty is to be subject to a normative requirement. Duties provide some justified reason for the action. Similarly, having an epistemic duty means being subject to a normative requirement. If $S$ is able to explain why he took A, claiming it was his duty, then he offers a justification for his doxastic action. Chisholm states that we have a formal epistemic duty as intellectual beings to try to do our best to achieve the epistemic end of believing truths and not believing falsehoods, in order to believe propositions if and only if they are true.

\section{Teleological normativity}

Parallels between ethical discourse and epistemological discourse in relation to the evaluative character of the concepts of justification, rationality and guarantee. The concept of epistemic justification is, in some sense, a normative concept. The concern is to describe rules that cannot be violated by an agent. There are two points of view regarding the normativity of moral judgments: the 


\section{Philosophy International Journal}

teleological and the deontological. Epistemic judgments are more naturally understood in teleological lines.

For a teleologist, the epistemic value of doxastic attitudes depends on a non-epistemic value that gives rise or seeks to give rise. Teleological theories place the obligatory and the epistemically good in dependence on the non-epistemically good. To find out what is the right doxastic attitude, one must first find out what is good, in the non-epistemic sense, and then ask whether the doxastic attitude in question promotes or is intended to promote the good in that sense.

According to Richard Feldman, it seems reasonable to interpret the term "law" not as "duty", but as "objective" or "end", since it only tells us what we should obtain, but not the means and the ways in which obtain such ends or objectives.

Faced with two extreme positions, believe in everything, in order to believe in many or all truths; and to believe in little, in order to believe in as few falsehoods as possible, it is necessary to find a suitable mix in order to achieve epistemic excellence.

\section{Epistemic ethics}

Richard Feldman argued that prudential, moral and epistemic merit does not always coincide. On the other hand, it is possible to imagine a situation in which someone, when doing $\mathrm{x}$, at the same time fulfills his prudential, epistemic and moral duty or obligation. If fulfilling your epistemic duty is, at a given moment, incompatible with fulfilling your moral duty at that moment, then which one should be fulfilled? Do moral duties always outweigh epistemic duties? For Feldman, there is no problem with the idea that duties of the same type can have equal importance. The relevant point is that there may be some scale of values. Fulfilling a duty contributes more than fulfilling the other to achieve that which has intrinsic value. The problem, according to Feldman, is that there is no clarity on how to conduct an assessment with a rating scale of various types of duties.

Epistemic factors can lead in some cases to results different from those achieved by moral or prudential duties. The view that the concept of justification is defined in terms of epistemic doxastic duties is called epistemic deontology. The difference between epistemic and moral duty is that one must believe, disbelieve, or suspend judgment in the face of a proposition, in which one can lawfully perform or not perform an action.

Epistemic Deontologism deals properly with epistemic duties in relation to beliefs. He explains epistemic justification by means of doxastic epistemic duties. Therefore, duties do not require the subject to seek or consider more evidence, only to take doxastic attitudes according to some epistemic rule.

The result of the phenomenology of belief has cast doubt on whether people have the ability to control their beliefs as they have the ability to control their actions. People rarely have voluntary control over their beliefs.

There is dissimilarity with Ethics. There is a distinction between objective and subjective justification. Having subjective epistemic justification does not seem to be sufficient to achieve the desired epistemic excellence. Some try to identify the deontological notion with objective epistemic justification, but this seems to put aside the fundamental characteristic of this notion, namely, the epistemic irreprehensible [4-9].

\section{References}

1. Goldman A (2001) Internalism Exposed. Reprinted. In: Steup M (Ed.). pp: 115-133.

2. Yolton JW (1996) Dicionário Locke. Rio de Janeiro: Zahar.

3. Plantinga A (1993a) Warrant: The Current Debate. Oxford: Oxford University Press.

4. Chisholm R (1966) Theory of Knowledge. Englewood Cliffs: Prestice-Hall. $2^{\text {nd }}$ (Edn.).

5. Feldman R (1988) Epistemic Obligation. Philosophical Perspectives 2. pp: 235-256.

6. Feldman R (1998) Epistemology and Ethics. In: Craig E.

7. Feldman R (2000) The Ethics of Belief. Philosophy and Phenomenological Research 3. pp: 667-695.

8. Goldman A (1986) Epistemology and Cognition. Cambridge: Harvard University Press.

9. Locke J (1959) An Essay concerning Human Understanding. New York: DOVER.

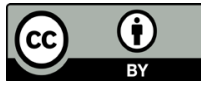

